\section{Effect of Thermotherapy on Elimination of Apple Stem Grooving Virus and Apple Chlorotic Leaf Spot Virus for In vitro-cultured Pear Shoot Tips}

\author{
Liping Wang, Guoping Wang, Ni Hong, ${ }^{1}$ Rongrong Tang, and \\ Xiaoyun Deng \\ National Indoor Conservation Center for Virus-free Gemplasm of Fruit Crops; \\ College of Plant Science and Technology, Huazhong Agricultural University, \\ Ministry of Education, Wuhan, Hubei 430070 P.R. China
}

\author{
Hong Zhang \\ Honghe College, Mengzi, Yunnan 661100 P.R. China
}

Additional index words. dot-blot hybridization, ELISA, meristem culture, virus elimination

\begin{abstract}
Apple stem grooving virus (ASGV) and apple chlorotic leaf spot virus (ACLSV) are two major viruses of pear. In this study, in vitro thermotherapy was carried out at $37^{\circ} \mathrm{C}$ for 25, 30 and 35 days followed by subculturing of meristem tips of different sizes to eliminate ASGV and ACLSV from pear plants. Virus titers in heat-treated shoot tips were evaluated by ELISA testing of regenerated plants. Results showed that thermotherapy for $\mathbf{3 5}$ days significantly decreased the titer of ASGV and ACLSV in cultures regenerated from tips of main and axillary shoots, especially in those from explants $1 \mathrm{~mm}$ in length from the tip of meristems. Dot-blot hybridization of biotinylated cDNA probes derived from ACLSV and ASGV was used to detect these viruses in crude tissue extracts of in vitro-grown pear plants. Intense signals were consistently detected in untreated plant samples equivalent to less than $0.5 \mathrm{mg}$ tissue. Comparison of signals from dot-blot hybridization and ELISA absorbance values $\left(\mathbf{A}_{405}\right)$ confirmed that dot-blot hybridization had a higher sensitivity than PAS-ELISA. Dot-blot hybridization could detect viruses with a titer below the threshold level of ELISA. These results indicate that dot-blot hybridization is a useful tool for large-scale surveys of viruses, which facilitates the production of virus-free propagation materials in certification and sanitation programs. Results of PAS-ELISA and dot-blot hybridization showed that high virus elimination efficiency was achieved by a combination of thermotherapy for 35 days and in vitro culture of $1 \mathrm{~mm}$ meristem tips.
\end{abstract}

Apple stem grooving virus (ASGV) and apple chlorotic leaf spot virus (ACLSV) are two important viruses of apple and pear, which have a worldwide distribution. In commercially cultivated apple and pear trees, these viruses do not usually cause obvious symptoms, but they decrease growth and productivity in infected trees (Desvignes and Boye, 1989; Plese et al., 1975), and in some cases cause tree decline. ACLSV can also infect stone-fruit trees such as peach and plum causing pseudo-pox symptoms (Nemeth, 1986). Previous surveys indicated that $>80 \%$ of pear trees in China are infected by both viruses, and for some varieties, infection percentage is about $100 \%$ (Wang et al. 1994). To date, no insect vectors have been found for transmission of ASGV and ACLSV. Grafting with infected materials is the known route by which these viruses spread. Thus, use of certified healthy propagation materials might representa

\footnotetext{
Received for publication 21 Jan. 2005. Accepted for publication $22 \mathrm{Feb}$. 2006. This work was carried out with financial grant no. 30370997 from National Natural Science Foundation of China. We express gratitude to T. Hsiang, Dept. Environmental Biology, University of Guelph, Guelph, Ontario, Canada, and Sh. Y. Wan, Huazhong Agricultural University, China, for critical reading of the manuscript.

${ }^{1}$ Corresponding author; e-mail whni@mail.hzau. edu.cn.
}

screening supposedly virus-free in vitro plants. RT-PCR has been widely used since the 1990s for the detection of plant RNA viruses because of its high sensitivity (Kinard and Scott, 1996; Pappu et al., 2005; Singh, 1998). The efficiency of RT-PCR depends on the quality of RNA (MacKenzie et al., 1997). In pear trees, polyphenolic compounds, polysaccharides and some other substances have a major effect on RT-PCR, and may restrict its application for large-scale detection (Deng et al., 2004). Hybridization based on cDNA or cRNA probes is a technically simple and powerful method for virus detection, especially with the introduction of nonradioactive probes, which has greatly expanded its application (Dietzgen et al., 1994; Galipienso et al., 2004; Harper and Creamer, 1995; Ma's et al., 1993; Narvaez et al., 2000).

For obtaining a higher efficiency of virus elimination, it is vital to determine the distribution of viruses in shoot tips under treatment so that meristem tips of proper size can be selected for regeneration, and important to establish a sensitive method for the detection of lowtiter viruses for treatment evaluation. In this study, the effect of thermotherapy periods on ASGV and ACLSV in tips of in vitro cultured pear plants was evaluated by both ELISA and dot-blot hybridization. The sensitivity of both methods was compared based on testing of crude extracts from in vitro-grown pear plants. The purposes of this study were to provide some information on obtaining higher efficiency of virus elimination and to establish an effective method for detection of low-titer viruses after sanitation treatments.

\section{Materials and Methods}

Plant materials. Pyrus pyrifolia 'Huanghua', widely grown in central and southern China, was used for the experiments. Shoots were collected from the National Germplasm Conservation Center of Pyrus pyrifolia (in Wuhan, Hubei) in spring and tested for the presence of ASGV and ACLSV by PAS-ELISA. Samples that gave positive reactions for both viruses were assayed for confirmation by immuno-capture RT-PCR (IC-RT-PCR) and used as starting materials. For the establishment of in vitro cultures, apical meristems about $5 \mathrm{~mm}$ in length were surface sterilized and meristemtips about $1 \mathrm{~mm}$ long were excised and plated on modified Murashige and Skoog (MS) medium containing $0.2 \mathrm{mg} \cdot \mathrm{L}^{-1}$ 6-benzylaminopurine (6-BA), $1.0 \mathrm{mg} \cdot \mathrm{L}^{-1}$ 3-indole-butyric acid (IBA), $30 \mathrm{~g} \cdot \mathrm{L}^{-1}$ sucrose and $7.5 \mathrm{~g} \cdot \mathrm{L}^{-1}$ agar. Explants were incubated in a growth room at $24 \pm 1{ }^{\circ} \mathrm{C}$ with a $16 \mathrm{~h}$ photoperiod and $2000 \mathrm{~lx}$ light intensity. After 30 or $35 \mathrm{~d}$, viable cultures were numbered and transferred onto newly prepared MS medium. The presence of ACLSV and ASGV was assessed again in each of all plants from different explants as above. Plants positive for both viruses were propagated for the following treatments.

In vitro thermotherapy. Shoot tips about 5.0 $\mathrm{mm}$ in length were excised from in vitro-cultured plants and transferred onto MS medium. Cultures were placed in a growth chamber at 
Table 1. PAS-ELISA detection of ASGV from in vitro cultures regenerated from thermotherapy.

\begin{tabular}{lcccc}
\hline & $\begin{array}{c}\text { Treatment } \\
\text { period } \\
\text { Source }\end{array}$ & \multicolumn{3}{c}{ Size of meristem tips $(\mathrm{mm})$} \\
\hline Main shoots & $(\mathrm{d})$ & 1 & 2 & 5 \\
& 35 & $0.052^{\mathrm{z}}$ & 0.086 & 0.094 \\
& 30 & 0.179 & 0.145 & 0.158 \\
Axillary shoots & 25 & 0.121 & 0.107 & 0.148 \\
& 35 & 0.073 & 0.137 & 0.105 \\
Untreated shoots & 30 & 0.096 & 0.110 & 0.098 \\
Negative control & 25 & 0.145 & 0.149 & 0.250 \\
\hline
\end{tabular}

${ }^{\mathrm{z}}$ Absorbance values at $\mathrm{A}_{405}$

Table 2. PAS-ELISA detection of ACLSV from in vitro cultures regenerated from thermotherapy.

\begin{tabular}{lcccc}
\hline & $\begin{array}{c}\text { Treatment } \\
\text { period } \\
\text { Source }\end{array}$ & \multicolumn{3}{c}{ Size of meristem tips $(\mathrm{mm})$} \\
\hline Main shoots & 35 & 1 & 2 & 5 \\
& 30 & $0.072^{\mathrm{z}}$ & 0.135 & 0.131 \\
& 25 & 0.121 & 0.138 & 0.140 \\
Axillary shoots & 35 & 0.121 & 0.148 & 0.148 \\
& 30 & 0.051 & 0.062 & 0.069 \\
Untreated shoots & 25 & 0.080 & 0.104 & 0.085 \\
Negative control & & 0.097 & 0.093 & 0.117 \\
\hline
\end{tabular}

${ }^{2}$ Absorbance values at $\mathrm{A}_{405}$

$37^{\circ} \mathrm{C}$ with a $16 \mathrm{~h}$ photoperiod and about 1500 lx light intensity after a pretreatment at $32^{\circ} \mathrm{C}$ for $2 \mathrm{~d}$. Meristem tips of 1.0, 2.0, and $5.0 \mathrm{~mm}$ in length were dissected from the main (three meristem tips of each length) and axillary (two meristem tips of each length) shoots after treatment for 25,30 , or $35 \mathrm{~d}$ respectively, and then cultured on the same MS medium as above.

Virus detection. In vitro-cultured plants regenerated from heat-treated shoot tips were subcultured every 4 to 5 weeks up to three times and tested for ASGV and ACLSV by ELISA and dot-blot hybridization. Leaves of in vitro-cultured plants, including healthy and untreated control plants, were collected and tested by PAS-ELISA using antisera against ASGV and ACLSV isolates from apple (Hong et al., 1997; Hong et al., 1999). These antisera were verified to be as effective as commercial DAS-ELISA kits (Bioreba, Nyon, Switzerland) for the detection of ASGV and ACLSV of pears in previous trial (data not shown). Results were recorded as absorbance values at $405 \mathrm{~nm}\left(\mathrm{~A}_{405}\right)$.

For dot-blot hybridization, plasmids containing a cloned cDNA of a 582 bp CP gene (Accession no.AY728180) of aCLSV isolate from peach and a $500 \mathrm{bp}$ fragment covering $62.7 \%$ of the $\mathrm{CP}$ gene of a ASGV isolate from pear (Zheng et al., 2005), respectively, were digested by restriction enzymes. Cloned cDNA fragments were gel purified using the PCR Fragment Recovery Kit (TaKaRa, Dalian, China) and were biotin-labeled using Phototope-Starkit(New England Biolabs Inc). Crude extracts were prepared from leaves of the in vitro-cultured and control plants by grinding tissues $(100 \mathrm{mg})$ in $0.6 \mathrm{~mL} 0.02 \mathrm{M}$ phosphate buffered saline tween-20 (pH 7.2, containing $2 \%$ polyvinyl pyrrolidone and $0.1 \%$ BSA) and the supernatants were collected after centrifugation for $15 \mathrm{~min}$ at $12000 \mathrm{rpm}$. Aliquots $(2.5 \mu \mathrm{L})$ of each extract sample were spotted onto nylon membranes (Hybond-N ${ }^{+}$, Amersham Pharmacia Biotech). Membranes were air dried and UV-irradiated $(70 \mathrm{~mJ})$ in a cross-linking oven, pre-hybridized for 6 to $7 \mathrm{~h}$ at $68^{\circ} \mathrm{C}$ in prehybridization solution $(6 \times \mathrm{SSC}$, $5 \times$ Denhardt's reagent, $0.5 \%$ SDS), and then hybridized in the same solution with denatured probe at $68{ }^{\circ} \mathrm{C}$ for $12 \mathrm{~h}$. After hybridization, membranes were developed using reagents and following protocols supplied by Phototope-Star detection kit and exposed to X-ray film.

\section{Results}

Detection of ASGV and ACLSV from in vitro pear plants. A total of 15 tips were dissected from one plant of 'Huanghua' pear positive for both ASGV and ACLSV and cultured on MS medium. Five explants survived. After two to three rounds of subculturing, all plants were assayed by PAS-ELISA. Results showed that all subcultures were positive for both viruses, but with some differences in $\mathrm{A}_{405}$ values. Some plants with low $\mathrm{A}_{405}$ were discarded and others were propagated for later treatments.

Effect of different thermotherapy periods combined with different meristem sizes on the virus titer of regenerated in vitro pear plants. In total, 50 in vitro-cultured plants were heattreated and 32 plants survived until day 35. Tips of different sizes were dissected from the main and axillary shoots of 27 in vitro heat-treated plants after treatment for 25,30 , or $35 \mathrm{~d}$. All regenerated plants were assayed for ASGV and ACLSV by PASELISA. Virus titers were roughly evaluated by their $\mathrm{A}_{405}$ values in ELISA. Results indicated that periods of thermotherapy had significant effects on titers of these viruses in tips of in vitro- cultured plants for both ASGV (Table 1) and ACLSV (Table 2). When the treatment period lasted $35 \mathrm{~d}$, titers of ASGV and ACLSV in plants regenerated from 1-, 2-. or 5-mm tips decreased greatly, especially in those from 1-mm tips, which had $\mathrm{A}_{405}$ values near that of the negative control, whereas all plants regenerated from un-treated 1-, 2-, or 5-mmlong shoot tips were positive. Compared with main shoots, virus titers in plants from axillary shoots decreased to a lesser extent.

Detection of ASGV and ACLSV of in vitro plants from thermotherapy by dot-blot hybridization. The efficacy of biotinylated probes specific to ASGV and ACLSV was determined by making serial 10 -fold dilutions in $0.1 \mathrm{~N} \mathrm{NaOH}$. When $1 \mu \mathrm{L}$ aliquots of these probes and prebiotinylated markers provided with the labeling kit were spotted onto nylon membranes, visible signals from both probes were obtained in a dilution up to $1: 10^{6}$ (Fig. 1 , rows $\mathrm{C}$ and $\mathrm{S}$ ).

Crude extracts from in vitro-cultured plants of 'Huanghua' that were ELISA-positive for ASGV and ACLSV were used in dot-blot hybridization to determine the efficiency and specificity of biotinylated cDNA probes. Strong signals were obtained from samples positive to both viruses but not from extracts of healthy plants (Fig. 2, rows A and B).

The same plants regenerated from heattreated in vitro plants tested by ELISA were retested by dot-blot hybridization. Figures 2 and 3 show some hybridization results for the same samples as in Tables 1 and 2, respectively. Signal intensity was related to virus titers. For plants regenerated from main shoots, signals decreased when treatment periods were prolonged, and within the same treatment period, virus titers decreased with the decreasing size of the explants. Some plants regenerated from 1 $\mathrm{mm}$ tips gave no signals (Fig.2, rows $\mathrm{C}$ and c). The same effect of tip sizes on virus titers was observed in plants regenerated from axillary shoots that had developed during the treatment, especially for ACLSV from axillary shoots heat-treated for $35 \mathrm{~d}$. The change of signal intensity according to treatment periods was smaller in plants regenerated from axillary shoot tips than from main shoot tips (Fig. 3).

Fig. 1. Titers of biotin-labeled probes specific to ASGV and ACLSV. Specific biotinylated-probes forASGV (s), ACLSV (c), and biotinylated-DNA marker $(\mathrm{M})$ provided with the labeling kit were spotted to a nylon membrane with serial dilutions. Lanes 1 to $6=$ dilution $10^{-1}$ to $10^{-6}$.

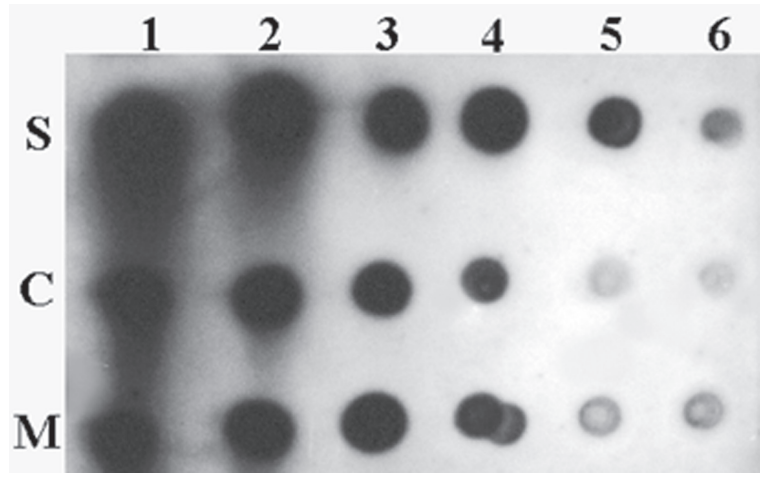



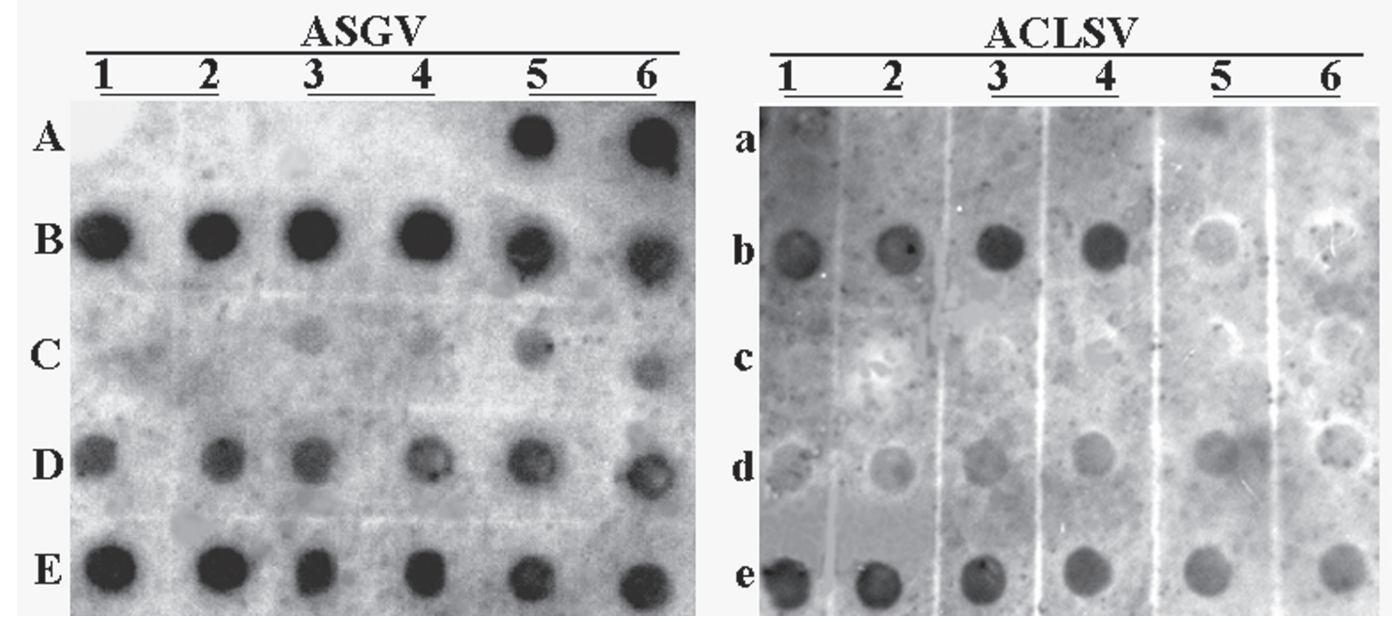

Fig. 2. Detection of ASGV and ACLSV from main shoots with thermotherapy by dot-blot hybridization. Crude extracts from plants regenerated from heat-treated main shoots for 35 (rows $\mathrm{C}$ and c), 30 (rows $\mathrm{D}$ and $\mathrm{d}$ ) and $25 \mathrm{~d}$ (rows E and e) were spotted on nylon membranes. The membranes were hybridized with biotinylated specific probes for ASGV or ACLSV. Lines 1 to 2, 3 to 4, and 5 to 6 are samples regenerated from meristem-tips with sizes of 1,2, and $5 \mathrm{~mm}$, respectively. Extracts from in vitro plants without thermotherapy were used as positive control (B1-B6 and b1-b4), and extracts from healthy seedling of pear were used as negative control (A1-A4 and a1-a6); Plasmids containing cloned cDNA fragments of ASGV were loaded on A5-A6 as positive control. Extracts from an untreated in vitro pear sample that showed negative reaction in PAS-ELISA test were loaded on b5 and b6.

Comparison of the sensitivity of ELISA and dot-blot hybridization for the detection of $A S G V$ and $A C L S V$ of in vitro pear plants. Comparison of signals from dot-blot hybridization and ELISA absorbance values revealed that samples with higher absorbance values usually developed stronger hybridization signals. Samples with absorbance value near that of the negative control developed very weak or no signals.

Although ELISA has been widely applied

Fig. 3. Detection of ASGV and ACLSV from axillary shoots with thermotherapy by dot-blot hybridization. Crude extracts from negative controls (row A) and plants regenerated from axillary shoots heat-treated for 35 (row B), 30 (row C), and $25 \mathrm{~d}$ (row D) were spotted on nylon membranes. The membranes were hybridized with biotinylated specific probes for ASGV or ACLSV. Lane 1,2 and 3 are samples regenerated from meristem tips with sizes of 1,2 , and $5 \mathrm{~mm}$, respectively.
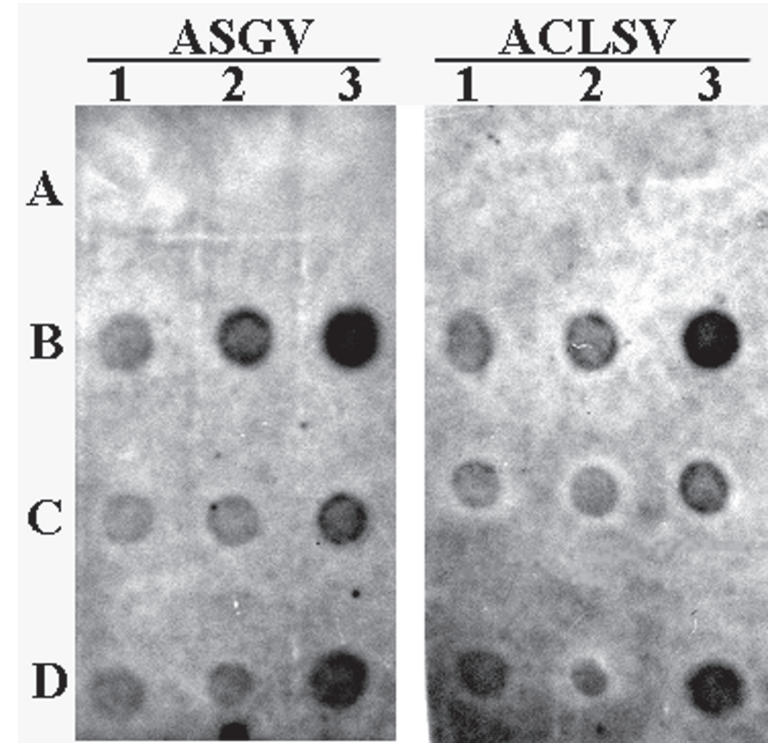

to the detection of fruit tree viruses, there is not an absolute standard for the assessment of positive or negative reaction. Usually if the absorbance value of a positive sample is 1.7 to 2 times higher than a negative control $(\mathrm{P} / \mathrm{N})$, it is considered a positive reaction, but this depends on the experience of the operator. For samples with low virus titers, it is sometimes difficult to judge negative or positive reaction based on $\mathrm{P} / \mathrm{N}$ ratios. For virus elimination by meristem-tip culture combined with thermotherapy, more attention is given to screening virus-free materials. Therefore, a correct assessment of a negative reaction has more importance than of a positive reaction in this case. Table 3 presents the virus elimination results following two different standards in ELISA, and a comparison with results obtained by dot-blothybridization. In this study, when samples with ELISA P/N $<1.5$ were classified as negative, agreement between ELISA and dot-blot hybridization for ASGV or ACLSV detection of plants regenerated from main shoots was $85.2 \%(23 / 27)$ or $96.3 \%(26 / 27)$, respectively (Table 3). For plants from axillary shoots, agreement between the two detection methods was higher, as only one plant of 18 gave a different response when $\mathrm{P} / \mathrm{N}<1.5$ was used to judge negative reaction. PAS-ELISA gave higher virus-free percentages for all treatments, confirming the higher sensitivity of dot-blot hybridization.

Efficiency of different thermotherapy periods combined with different meristem tip sizes on virus elimination. Based on detection results ofPAS-ELISAand dot-blot hybridization, samples showing negative reaction in one of both tests were retested by dot-blot hybridization after an additional subculture. Virus-free condition was judged based on the lack of hybridization signals. Higher virus elimination efficiency was achieved by a combination of thermotherapy for $35 \mathrm{~d}$ and culture of $1 \mathrm{~mm}$ meristem-tips. In this case, 2 of 3 and 1 of 3 cultures regenerated from main shoot tips were free of ACLSV and ASGV, respectively, whereas only 1 of 2 cultures from axillary shoot tips was free from both viruses (Table 4). With thermotherapy for $35 \mathrm{~d}$ combined with 2- or 5-mm explants, only one culture from each tip size was free from ACLSV.

\section{Discussion}

Meristem culture is a widely used system for plant virus elimination and the conservation of virus-free germplasm. Since high temperatures can inhibit virus multiplication and movement, thermotherapy combined with meristem tip culture can greatly improve virus elimination efficiency by augmenting the virus-free region of treated shoot tips. However, little is known on the effect of thermotherapy duration on the distribution of viruses in plant shoot tips, which is important for their efficient elimination. This study showed a great effect of high temperature on the distribution of both ASGV and ACLSV in tips of in vitro-cultured pear shoot tips, and the effect was dependent on treatment time. When thermotherapy lasted $35 \mathrm{~d}$, the titer of ASGV and ACLSV decreased towards the tips of shoots. This tendency was more obvious in main shoots than in axillary shoots. Our results are in consistency with previous reports that ACLSV is more sensitive to high temperature than ASGV. ASGV is one of the most recalcitrant viruses to be eliminated by any procedures, even when heat therapy and meristem dissection are applied (Campell, 1968; Cropley, 1968; Knapp et al., 1995). Although ACLSV can be relatively easily eliminated from apple by short periods of heat treatment or by meristem-tip culture, in this study we found that a heat treatment for $>35 \mathrm{~d}$ followed by meristem-tip culture with tips $<1 \mathrm{~mm}$ in length was necessary for elimination of the virus from pear.

The reliability of screening virus-free in vitro plants from thermotherapy was affected by virus titer. After the treatment, some plants regenerated from different meristem tips had absorbance values below the threshold level of ELISA. In this case, using a lower $\mathrm{P} / \mathrm{N}$ value to judge positive or negative reaction could reduce the possibility of screening false negative plants. Knapp et al. (1995) reported that ASGV was positive or around threshold level and no ACLSV positive was found after $33 \mathrm{~d}$ of thermotherapy by DAS-ELISA and immuno-tissue printing, but the titer of ASGV from in vitro apple plants increased dramati- 
Table 3. Comparison of ELISA and dot-blot hybridization tests against ASGV and ACLSV from in vitro cultures regenerated from thermotherapy.

\begin{tabular}{|c|c|c|c|c|c|}
\hline \multirow{3}{*}{$\begin{array}{l}\text { Source of } \\
\text { in vitro } \\
\text { plants }\end{array}$} & \multirow[b]{3}{*}{ Virus } & \multirow{3}{*}{$\begin{array}{c}\text { Tested } \\
\text { cultures } \\
\text { (no.) }\end{array}$} & \multicolumn{3}{|c|}{ Negative cultures (no.) } \\
\hline & & & \multicolumn{2}{|c|}{ ELISA test ${ }^{2}$} & \multirow{2}{*}{$\begin{array}{c}\text { Dot-blot } \\
\text { test }\end{array}$} \\
\hline & & & I & II & \\
\hline \multirow[t]{2}{*}{ Main shoots } & ASGV & 27 & 6 & 14 & 2 \\
\hline & ACLSV & 27 & 6 & 8 & 5 \\
\hline \multirow[t]{2}{*}{ Axillary shoots } & ASGV & 18 & 2 & 2 & 1 \\
\hline & ACLSV & 18 & 2 & 4 & 1 \\
\hline
\end{tabular}

${ }^{2}$ Negative reaction is based on $\mathrm{A}_{405}$ of tested samples/ $\mathrm{A}_{405}$ of negative control, $<1.5$ (I) or $<1.7$ (II).

Table 4. Efficiency of thermotherapy combined with meristem-tip culture on generating virus-free plants.

\begin{tabular}{|c|c|c|c|c|c|c|c|}
\hline \multirow{3}{*}{$\begin{array}{l}\text { Sources of } \\
\text { in vitro } \\
\text { cultures }\end{array}$} & \multirow{3}{*}{$\begin{array}{c}\text { Size of } \\
\text { meristem tips } \\
(\mathrm{mm})\end{array}$} & \multicolumn{6}{|c|}{ Thermotherapy period (d) } \\
\hline & & \multicolumn{3}{|c|}{ ASGV } & \multicolumn{3}{|c|}{ ACLSV } \\
\hline & & 25 & 30 & 35 & 25 & 30 & 35 \\
\hline \multirow[t]{3}{*}{ Main shoots } & 1 & $0 / 3^{z}$ & $1 / 3$ & $1 / 3$ & $1 / 3$ & $0 / 3$ & $2 / 3$ \\
\hline & 2 & $0 / 3$ & $0 / 3$ & $0 / 3$ & $0 / 3$ & $0 / 3$ & $1 / 3$ \\
\hline & 5 & $0 / 3$ & $0 / 3$ & $0 / 3$ & $1 / 3$ & $0 / 3$ & $1 / 3$ \\
\hline \multirow[t]{3}{*}{ Axillary shoots } & 1 & $0 / 2$ & $0 / 2$ & $1 / 2$ & $0 / 2$ & $0 / 2$ & $1 / 2$ \\
\hline & 2 & $0 / 2$ & $0 / 2$ & $0 / 2$ & $0 / 2$ & $0 / 2$ & $0 / 2$ \\
\hline & 5 & $0 / 2$ & $0 / 2$ & $0 / 2$ & $0 / 2$ & $0 / 2$ & $0 / 2$ \\
\hline
\end{tabular}

${ }^{2}$ Virus-free cultures/regenerated cultures.

cally by the sixth month after thermotherapy and meristem dissection. In this study, small amounts of RNA from some ELISA-negative plants were detected by dot-blot hybridization. Negative plants will be retested after rooting and growing in a greenhouse.

Compared with RT-PCR, major advantages of RNA-based hybridization are that it allows simultaneous testing of large numbers of samples in a single membrane and is less affected by compounds of host plants. Dot-blot hybridization based on extracted RNA and tissue printing hybridization can give a sensitive detection of different plant viruses (Galipienso et al., 2004; Ma's et al., 1993; Stark-Lorenzen et al., 1997). However, the extraction of RNA or dsRNA is time consuming, and the application of tissue printing hybridization is limited by virus distribution in tissues. In this study, dot-blot hybridization based on crude extracts of plants was used to detect ACLSV andASGV of in vitro pear plants. Strong signals were consistently produced for untreated plant samples equivalent to $<0.5 \mathrm{mg}$ tissue. This method can detect viruses with a titer below the threshold level of ELISA. It could be a useful tool for large-scale surveys of viruses and screening of virus-free propagation materials in certification and sanitation programs. rological detection of apple stem grooving virus. Scientia Agr. Sinica 30:6-12.

Hong, N. and G.P. Wang. 1999. The purification of apple chlorotic leaf spot virus and the production of antiserum against the virus. China Fruits (1):15-18.

Kinard, G.R. and S.W. Scott. 1996. Detection of apple chlorotic leaf spot and apple stem grooving viruses using RT-PCR. Plant Dis. 80:616-621.

Knapp,E., V.Hanzer, H. Weiss, A. da Câmara Machado, A. da Clmara Machado, Q. Wang, B. Weiss, H. Katinger, and M. Laimer da Clmara Machado. 1995. New aspects of virus elimination in fruit trees. Acta Hort. 386:409-418.

Ma's, P., J.A. Sanchez-Navarro, M.A. Sanchez-Pina, and V. Palla's. 1993. Chemiluminiscent and chromogenic detection of cherry leaf roll virus with digoxigenin-labeled RNA probes. J. Virol. Methods 45:93-102.

MacKenzie D.J., M.A. McLean, S.Mukerji, and M. Green. 1997. Improved RNA extraction from woody plants for the detection of viral pathogens by reverse transcription polymerase chain reaction. Plant Dise. 81:222-226

Manganaris, G.A.,A.S. Economou, I.N. Boubourakas, and N.I. Katis. 2003. Elimination of PPV and PNRSV through thermotherapy and meristem-tip culture in nectarine. Plant Cell Rpt. 22:195-200.

Narvaez, G., B.S. Skander, M.A. Ayllon, L. Rubio, J. Guerri, and P. Moreno. 2000. A new procedure to differentiate citrus tristeza virus isolates by hybridisation with digoxigenin-labeled cDNA probes. J. Virol. Methods 85:83-92.

Campell, A.I. 1968. Heat sensitivity of some apple viruses. Tagungsber. DAL DDR (Berlin) 97:311-316.

Cieslinska, M. 2002. Elimination of Apple chlorltic leaf spot virus (ACLSV) from pear by in vitro thermotherapy and chemotherapy. Acta Hort. 596:481-484.

Cropley, R. 1968. Comparison of some latent apple viruses. Ann. Appl. Biol. 61:361-372.

Deng, X.Y., N. Hong, H.J. Hu, and G.P. Wang. 2004. Detection of latent viruses in Pyrus pyrifolia by IC-RT-PCR and TC-RT-PCR. J. Fruit Sci.21:569-572.

Desvignes, J.C. and R. Boye.1989. Different diseases caused by the chlorotic leaf spot virus on the fruit trees. Acta Hort. 235:31-38.

Dietzgen, R.G., Z. Xu, and P.Y. Teycheney. 1994. Digoxigenin labeled cRNA probes for the detection of two potyviruses infecting peanut (Arachis hypogaea). Plant Dis. 78:708-711.

Galipienso, L., M.C. Vives, L. Navarro, P. Moreno, and J. Guerri. 2004. Detection of citrus leafblotch virus using digoxigenin-labeled cDNA probes and RT-PCR. Euro. J. Plant Pathol. 110:175-181.

Harper, K. and R. Creamer. 1995. Hybridisation detection of insect-transmitted plant viruses with digoxigenin-labeled probes. Plant Dis. 79:563-567.

Hong, N., G.P. Wang, J.M. Yu, Y.F. Dong, and Z.P. Zhang. 1997. The isolation, purification and se-
Nemeth, M. 1986. Virus, mycoplasma and richettsia diseases of fruit trees. Martinus Nijhoff Publ.

Pappu, H.R., S.D. Wyatt, and K.L. Druffel. 2005. Dahlia mosaic virus: Molecular detection and distribution in dahlia in the United States. Hortscience 40:697-699.

Plese, N., E. Hoxha, and D. Milicic. 1975. Pathological anatomy of trees affected with apple stem grooving virus. Phytopathology 82:315-325.

Singh, R.P. 1998. Reverse-transcription polymerase chain reaction for the detection of viruses from plants and aphids. J.Virol. Methods 74: 125-138.

Stark-Lorenzen, P., M.C. Guitton, R. Werner, and H.P. Muhlbach. 1997. Detection and tissue distribution of potato viroid in infected tomato plants by tissue hybridization. Arch. Virol. 142:1289-1296

Wang, G.P., N. Hong, and Z.P. Zhang. 1994. Identification of virus species in pears cultivated in northern China. China Fruits (4): $1-4$

Zheng, Y.Y., G.P. Wang, and N. Hong. 2005. The biological characteristics and molecular identification of some apple stem grooving virus isolates. Acta Phytophylacica Sinica 32:266-270.

Zilka, S., E. Faingersh, A. Rotbaum, Y. Tam, S. Spiegel, and N. Malca. 2002. In vitro production of virusfree pear plants. Acta Hort. 596:477-479. 